\title{
Charge and discharge characteristics of different types of batteries on a hybrid electric vehicle model and selection of suitable battery type for electric vehicles
}

\author{
Yunus Emre Ekici ${ }^{*}$, Nusret Tan ${ }^{1}$ \\ 0000-0001-7791-0473, 0000-0002-1285-1991
}

${ }^{1}$ Inonu University, Engineering Faculty, Dept. of Electrical and Electronics Eng., 44280, Malatya, Turkey

\begin{abstract}
The choice of battery type for electric vehicles is of great importance. For electric vehicle manufacturers, this issue is the biggest engineering problem. An electric vehicle produced with the right battery type will undoubtedly be preferred by users. In this study, the charge and discharge characteristics of four different battery types with a fixed charger were investigated. The batteries were then placed on a hybrid electric vehicle model and the charge and discharge characteristics were examined. The batteries were then placed on a hybrid electric vehicle model and the charge and discharge characteristics were examined.
\end{abstract}

Keywords: Batteries, LiFePO4, Hybrid Vehicles, Electric Vehicles

\section{* Corresponding author \\ Yunus Emre Ekici \\ emreekici44@gmail.com}

Address: Inonu University, Engineering

Faculty, Dept. of Electrical and

Electronics Eng., 44280, Malatya,

Turkey

Tel: +905059154308

Research Article

Manuscript

Received 16.02.2019

Revised 30.10.2019

Accepted 14.11.2019

Doi: 10.30939/ijastech..527971

\section{Introduction}

Electric vehicles (EA) are considered to be the solution to greenhouse gas impacts on the world. By using electricity as fuel, it provides quieter, more environmentally friendly and more economical transportation. Electric vehicles use rechargeable battery technologies, but existing battery technologies are not yet capable of achieving the desired range and performance. Therefore, an effective and efficient battery management system (BMS) is needed to increase the range, life and performance of the original battery technologies used on vehicles.

The performance of an efficient and efficient battery management system is related to the correct calculation of the battery state of harge (SOC), which is one of the subparameters. Accurately calculating the battery charge rate and increasing the performance of electric vehicles is an important problem today and has become the subject of academic study [1]. Batteries are currently the most widely used electrical energy storage devices in vehicles. A battery is exposed to chemical reactions each time it is connected to a load or a source. Unfortunately, the chemical effect damages the natural and original structure of the battery. This causes the battery to gradually decrease its life.

The battery slimming process can be improved or delayed by changing the loading conditions of the battery. For example, a battery subject to over-temperature ranges or continuous charge and discharge cycles has a lower operating life than the battery operated under suitable conditions. In order for the batteries to operate safely, the conditions must also be safe and adequate, but the violation of the limits will adversely affect the safety of the batteries. In this case, the safety of the passengers in the vehicle will be a great danger. The key to the safe operation and long life of the battery is to ensure that the battery is always subject to the specified safe operating conditions so that the battery remains at the limit specified in the charging or discharging modes under the specified temperature

conditions [2], [3]. This system is called Battery 
Management System (BMS) for electric cars [4].

Although researches and developments on electric vehicles are thought to gain momentum due to the problems of greenhouse gas and oil reserves, the beginning of the development of electric vehicles is based on the 18th century [5]. The foundation of the first electric vehicle was laid by Michael Faraday in 1821, when fossil fuels were dominant [6]. Joseph Henry, a professor of mathematics living in Albany in 1831, built his first electric motor in an effort to understand electromagnetism. In 1834, with the study and understanding of Joseph Henry's efforts, Thomas Davenport developed the first rotary electric motor and built a miniature electric wagon running in a circle on the table. Thomas Davenport's miniature car could not bear the weight of the battery. Camille A. Faure, who lived in France in 1881, and Charles F. Brush, who lived in the United States in 1859 , revealed the idea of using a lead oxide paste to increase the capacity of the Planté battery. As a result, Charles Jeantaud produced an electric vehicle in France. The vehicle was designed with a Fulmen battery and a Gramme engine and had a Tilbury design [5], [7].

In 1902, the "electric carriage" developed by Woods was able to drive at a speed of $23 \mathrm{~km} / \mathrm{h}$. Woods then developed the first hybrid vehicle in the US in 1916, using an internal combustion engine and an electric motor [8]. Until the beginning of the 20th century, electric vehicles were technically more silent, the gear shifting was smooth and the starter movement was less expensive than handmade. However, in the 1920s, the development of crude oil reserves in the US state of Texas and the decline in gas prices, the beginning of mass production of internal combustion engine led by Henry Ford, the decline in vehicle prices, the improvement of the physical condition of the highways in the US and Europe and the increase in long-distance travel electric vehicles in the market has ended. Later, because of the oil crisis in 1974, oil prices were increasing and many countries were running out, many countries started to develop electric vehicles by providing support from official sources [5], [8].

In the 21 st century, the progress in the electric vehicles industry has continued with full speed. Long-range vehicles have been launched by different companies. In 2003, Tesla Motors was founded in California. In 2004, Tesla Motors began work on the $100 \%$ electric sports car Tesla Roadster, which was based on the popular and elegant Lotus Elise design. The automobile has changed the appearance of many electric cars and has encouraged some major car manufacturers to actually switch to the electric car market. In 2008, the Tesla Roadster became the first production electric vehicle to use lithium ion battery cells, as well as the first production electric vehicle with a range of over 200 miles (about $320 \mathrm{~km}$ ) on a single charge. In the same year, Barack Obama campaigned for the presidency, and when he was elected president by 2015 he would be on the US roads with 1 million plug-in hybrid and electric vehicles
[9].

Depending on the above developments, the battery type for electric vehicles can be said to be an engineering problem. With the development of battery technology, the vehicle sector has started to develop. In this study, four different types of batteries will be tested on a hybrid electric vehicle model and the most suitable battery type for electric vehicles will be determined. In our previous studies, different discharge tests were carried out with different types of batteries [10]-[12].

\section{Materials and Methods}

\subsection{Hybrid Electric Vehicle Model}

Almost all of the hybrid engines used today are formed by the addition of an internal combustion gasoline engine as well as the battery, electric motor and generator. This technology is $40-50 \%$ more efficient than gasoline engines. Because the hybrid motor technology is a smarter system and the engine determines five different modes of operation. Hybrid electric vehicles are wired and wireless. The hybrid electric vehicle model includes a diesel engine, electric motor and battery pack. Batteries are used according to diesel fuel and driving performance while driving. The batteries are charged by the user and charged for the next drive [7].

In the second model, there is no need for any cables to charge the batteries. The diesel engine in the hybrid vehicle allows the batteries to be charged by running the generator. In this study, the second model of electric vehicle is selected as simulation subject when it is studied to examine the characteristics of the battery at the time of driving.

\subsection{Battery Model}

The battery model is shown in Figure 1. Charge and discharge equations are presented in Equations 1 and 2. 


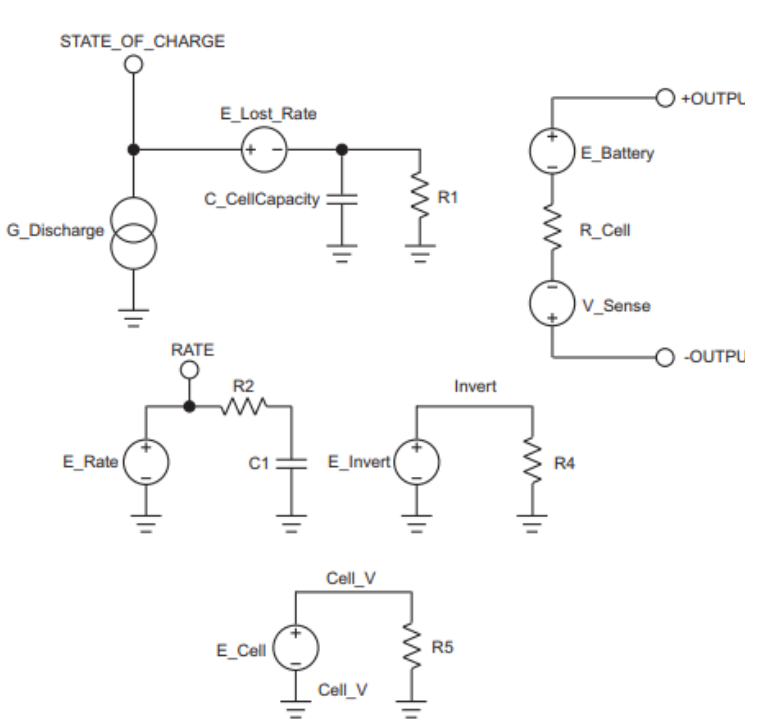

Fig. 1. Battery Model [13]

$$
\begin{aligned}
& E_{\text {Discharge }}=E_{0}-K \frac{Q}{Q-t} i^{*}-K \frac{Q}{Q-t} i t+A e^{-\beta i t} \\
& E_{\text {Charge }}=E_{0}-K \frac{Q}{0.1 Q+t} i^{*}-K \frac{Q}{Q-t} i t+A e^{-\beta i t}
\end{aligned}
$$

The charge-discharge characteristics of a lithium battery are obtained from the detailed model shown in Figure 2.

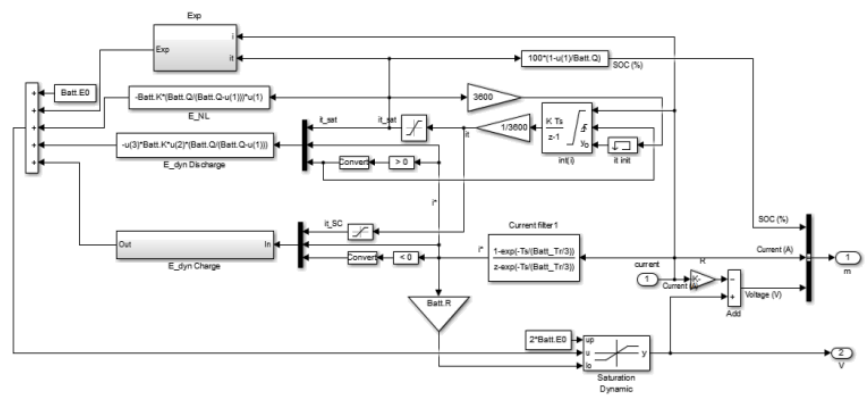

Fig. 2. Detailed Battery Model

\section{Simulation}

Simulation was prepared in SIMULINK under MATLAB ${ }^{\circledR} 2015 \mathrm{a}$. The ideal sampling frequency of the simulation is $1 \mathrm{kHz}$. The solvent was used as ode23tb. An overview of the Hybrid Electric Vehicle simulation is shown in Figure 3. In addition, the following assumptions are made for the simulation.

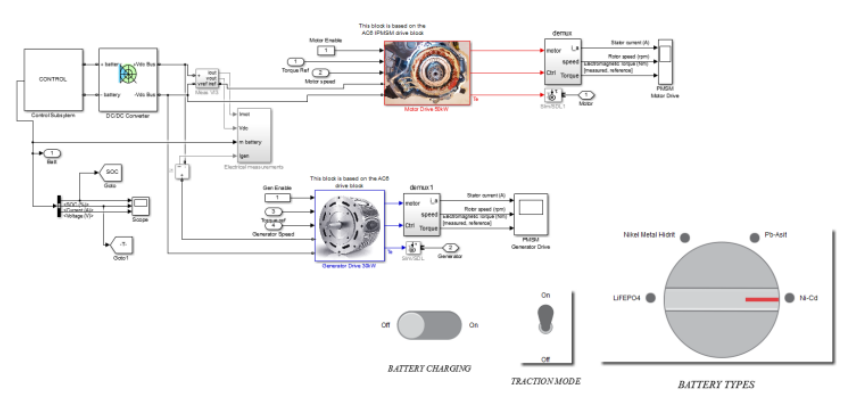

Fig. 3. Hybrid Electric Vehicle Simulation Model

A hybrid electric vehicle model was taken from Mathworks and LiFePO4, Nickel-metal-hydride, Lead-Acid and Nickel Cadmium type battery groups were installed. Four battery packs were created from different types of batteries with $14 \mathrm{kWh}$ of power. For the simulation, LiFePO4, Nickel-Metal-Hydride, Lead-Acid and Nickel Cadmium were used as battery groups. For the first test, the battery pack will be charged to $100 \%$ with the individual charger and the voltage cut off when the batteries are charged will be examined. The occupancy rate is $10 \%, 50 \%$, and $90 \%$. The reason for the different occupancy rate to be tested and tested is to examine whether the battery can be charged in any case and to inspect the disconnection when it is $100 \%$ full from any situation. The temperature of the system will also be checked while the batteries are charging. When the system overheats during charging, the charging will be stopped and the battery management system will keep the battery packs in a safe position. The block diagram for charging the batteries is shown in Figure 4.

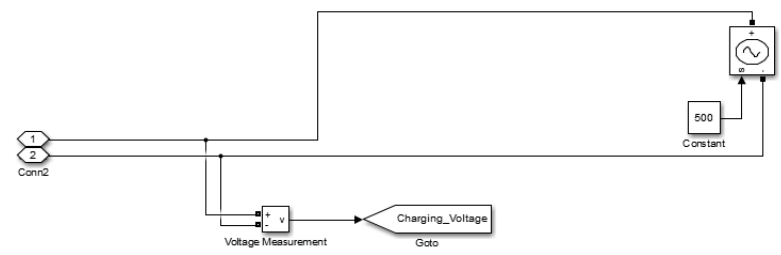

Fig. 4. Charging diagram

The 90 degree threshold for the simulation temperature data is set to $100 \%$ threshold for SOC. During charging, charging will stop if the system temperature exceeds 90 degrees. The block diagram for temperature control the batteries is shown in Figure 5. 


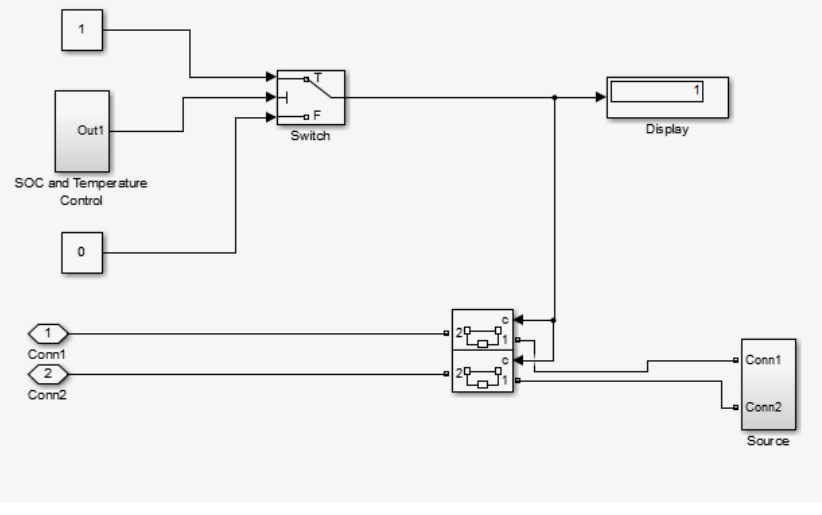

Fig. 5. Temperature and charging diagram

For the second test the batteries will be placed on a hybrid electric vehicle model and the simulation will be started with $20 \%$ SOC. The hybrid electric vehicle used in this simulation has one internal combustion engine, one electric motor and one generator. If the internal combustion engine cannot provide the required power according to the driving scenarios, the electric motor is activated and the batteries start to discharge. The battery management system (BMS) is active. If the battery level increases to $10 \%$ or the temperature value is over the specified value, the battery discharge is interrupted. The same applies to the charge. If the internal combustion engine provides the desired power, the electric motor is switched off, the generator works with the internal combustion engine and the batteries start to charge. If the full capacity of the batteries is $100 \%$, the BMS stops charging.

A driving scenario for the hybrid electric vehicle is identified and this scenario is shown in Figure 6. In the driving scenario, the accelerator pedal signals are modeled.

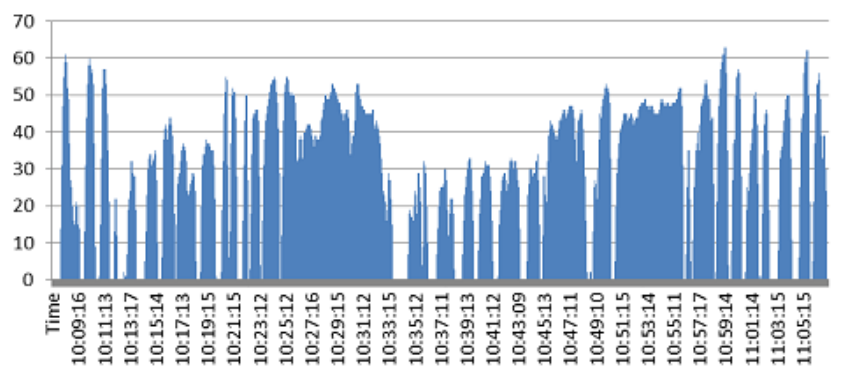

Fig. 6. Driving scenario

\section{Result and Discussion}

\subsection{LiFePO4 Charging Test}

Charging is started when the LiFePO4 battery pack has a voltage rating of $10 \%$. The battery pack has been selected with a value of $40 \mathrm{KW} 350 \mathrm{~V} 14 \mathrm{~kW}$. The LiFePO4 battery will also start charging with certain parameters. These are $407 \mathrm{~V}$ full charge voltage, $0.0875 \mathrm{ohm}$ internal resistance and 17.4 amps discharge current. The voltage of the DC source is also set to $500 \mathrm{~V}$.

When charging simulation is started for LiFePO4, the system temperature is equal to room temperature. The welding voltage is $500 \mathrm{~V}$ and the SOC value is $10 \%$. The current requirement of the battery pack was 79,03 amperes. Since the SOC and temperature data are below the desired threshold value, the system has started to operate healthy.

When the simulation was $50 \%$ SOC, the temperature of the batteries was measured as 39.4 degrees. The current current of the battery group was observed as 53,08 amperes. Charging is in progress as the temperature and SOC are below the threshold value. LiFePO4 reached 50\% charge rate $\mathrm{T}=65.94$ (after 25 minutes).

When the simulation reached $100 \%$ SOC, the temperature of the batteries was measured as 40 degrees. When the current current of the battery group was 9.4 amps, the system was shut down. This closure condition was achieved because the SOC value reached the desired threshold value. $\mathrm{LiFePO} 4$ reached $100 \%$ charge rate $\mathrm{T}=$ 237.1 (after 1.5 hours). For LiFePO4, the charge and discharge characteristics are presented in Figure 7.

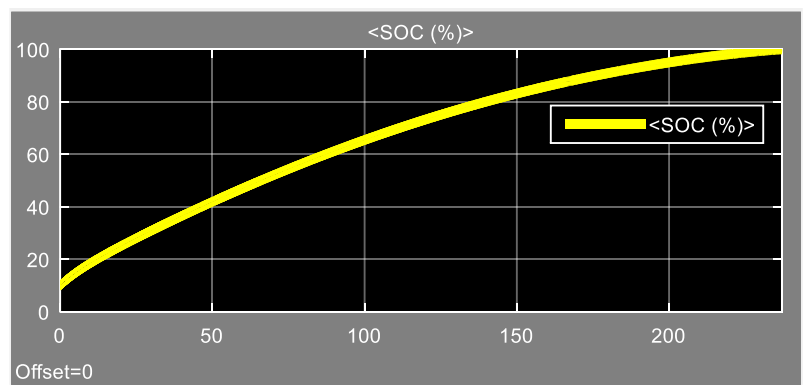

Fig. 7. Charging analysis for $\mathrm{LiFePO} 4$

\subsection{Nickel Metal Hydride Charging Test}

Charging is started when the Nickel Metal Hydride battery pack has a voltage rating of $10 \%$. The battery pack has been selected with a value of $40 \mathrm{KW} 350 \mathrm{~V} 14 \mathrm{~kW}$. Nickel Metal Hydride battery will also start charging with certain parameters. These are $412.7 \mathrm{~V}$ full charging voltage, $0.087 \mathrm{ohm}$ internal resistance and 8 amps discharge current. The voltage of the DC source is also set to $500 \mathrm{~V}$. When 
charging simulation is started for Nickel Metal Hydride, the system temperature is equal to room temperature. The welding voltage is $500 \mathrm{~V}$ and the SOC value is $10 \%$. The total current requirement of the battery pack was 124,8 amperes. Since the SOC and temperature data are below the desired threshold value, the system has started to operate healthy.

When the simulation reached $50 \%$ SOC, the temperature of the batteries was measured as 43.67 degrees. The current current of the battery group was observed as 33,09 amperes. Charging is in progress as the temperature and SOC are below the threshold value. Nickel Metal Hydride reached 50\% charge rate $\mathrm{T}=107.6$ (after 41 minutes).

When the simulation reached $100 \%$ SOC occupancy, the temperature of the batteries was measured as 43.75 degrees. When the current current of the battery group was 8 ampere, the system was shut down. This closure condition was achieved because the SOC value reached the desired threshold value. LiFePO4 reached $100 \%$ charge rate $\mathrm{T}=409.3$ (after 2.5 hours). For Nickel Metal Hydride, the charge and discharge characteristics are presented in Figure 8.

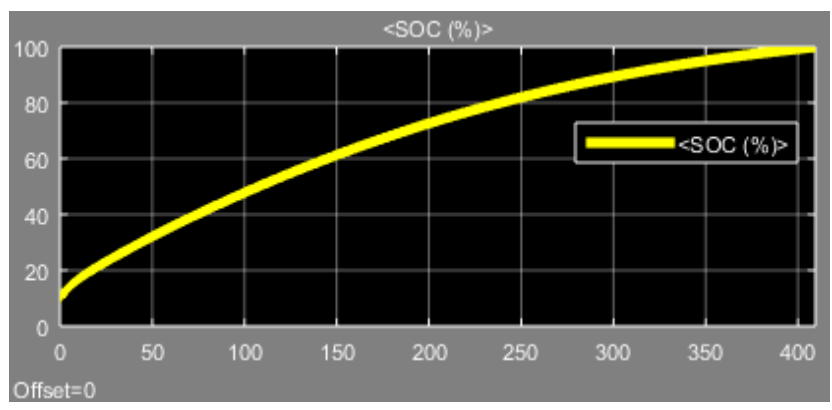

Fig. 8. Charging analysis for Nickel Metal Hydride

\subsection{Pb-Acit Charging Test}

The Lead Acid (Pb-Acid) battery pack has a voltage rating of $10 \%$ and charging starts. The battery pack has been selected with a value of $40 \mathrm{KW} 350 \mathrm{~V} 14 \mathrm{~kW}$. Lead Acid battery will also start charging with certain parameters. These are $381 \mathrm{~V}$ full charge voltage, $1.4 \mathrm{ohm}$ internal resistance and 0.5 amperes discharge current. The voltage of the DC source is also set to $500 \mathrm{~V}$. When charging simulation is started for Lead Acid, the system temperature is equal to room temperature. The welding voltage is $500 \mathrm{~V}$ and the SOC value is $10 \%$. The current requirement of the battery pack was 200.8 amperes. Since the SOC and temperature data are below the desired threshold value, the system has started to operate healthy.

The temperature of the batteries was measured as 43.74 degrees when the simulation was 50\% SOC. The current current of the battery group was 18,91 amperes. Charging is in progress as the temperature and SOC are below the threshold value. The lead acid battery reached $50 \%$ charge rate $\mathrm{T}=165$ (after 1 hour 3 minutes).

When the simulation reached $100 \%$ SOC, the temperature of the batteries was measured as 43.75 degrees. The current of the battery group was 3,38 amperes and the system was shut down. This closure condition was achieved because the SOC value reached the desired threshold value. Lead Acid battery reached $100 \%$ charge rate $\mathrm{T}=781.1$ (after 5 hours). For Lead Acit battery, the charge and discharge characteristics are presented in Figure 9.

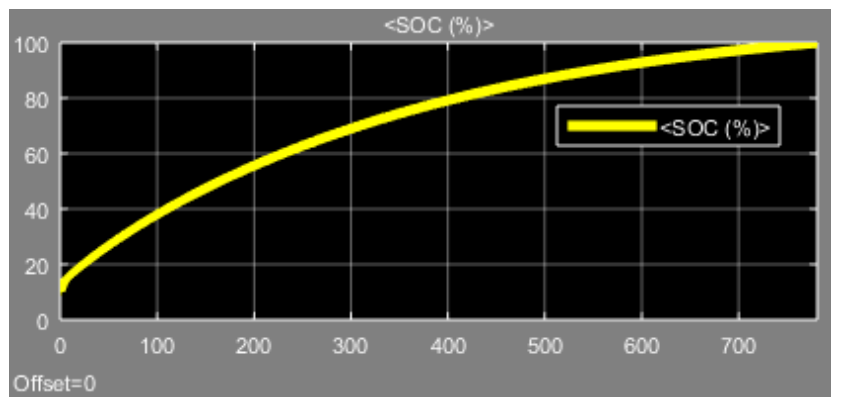

Fig. 9. Charging analysis for Lead Acit

\subsection{Nickel Cadmium Charging Test}

Charging is started when the Nickel Cadmium (Ni-Cd) battery pack has a $10 \%$ voltage rating. The battery pack has been selected with a value of $40 \mathrm{KW} 350 \mathrm{~V} 14 \mathrm{~kW}$. Nickel Kadminyum battery will also start charging with some special parameters. These are $400 \mathrm{~V}$ full charge voltage, 1,167 ohm internal resistance and 0,6 amperes discharge current. The voltage of the DC source is also set to $500 \mathrm{~V}$. When charging simulation is started for Nickel Cadmium, the system temperature is equal to room temperature. The welding voltage is $500 \mathrm{~V}$ and the SOC value is $10 \%$. The total current of the battery pack was 135,3 amperes. Since the SOC and temperature data are below the desired threshold value, the system has started to operate healthy.

When the simulation reached $50 \%$ SOC, the temperature of the batteries was measured as 43.69 degrees. The current current of the battery group was 34,11 amperes. Charging is in progress as the temperature and SOC are below the threshold value. Nickel Cadmium battery reached 50\% charge rate $\mathrm{T}=108$ (after 41 minutes).

When the simulation reached $100 \%$ SOC occupancy, the temperature of the batteries was measured as 43.75 degrees. The current current of the battery group was 7.96 ampere and the system was shut down. This closure condition was achieved because the SOC value reached the desired threshold value. Nickel cadmium battery reached $100 \%$ charge rate $T=426,8$ ( 2 hours 40 minutes later). For Nickel Cadmium battery, the charge and discharge characteristics are presented in Figure 10. 


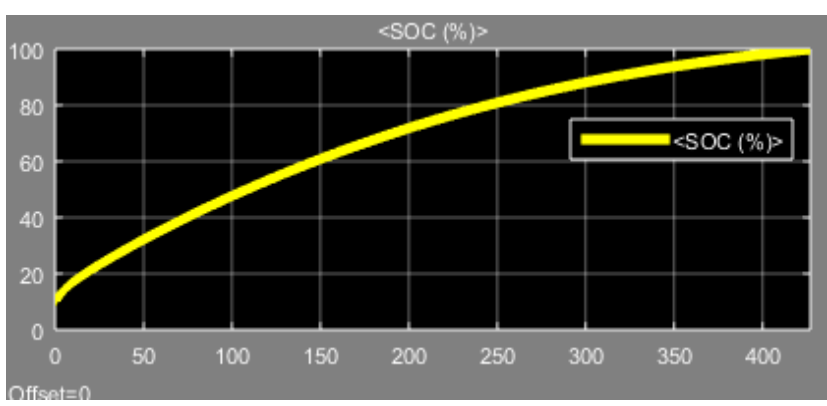

Fig. 10. Charging analysis for Nickel Cadmium

As a result of the four tests performed above, the batteries were properly charged. When the graphs were analyzed, it was observed that each battery pack had different instantaneous current in 10\%, 50\% and $100 \%$ SOC and the simulation time was different for each battery pack. This is due to the fact that even though the battery packs are chosen at equal power, their internal resistance and chemical structure are different. As a result of the analyzes, it is observed that $\mathrm{LiFePO} 4$ battery is charged in 1.5 hours, Nickel Metal Hydride battery is charged in 2.5 hours, Lead Acid battery is in 5 hours and Nickel Cadmium battery is charged in 2 hours and 40 minutes. When the initial conditions are equal, the fastest battery type is $\mathrm{LiFePO} 4$ and the slowest battery is Lead Acid. In addition, it has been determined that the highest starting current capacity is in Lead Acid battery. The flow data obtained from the simulation and the time until the threshold occupancy rate is presented in Tables 1.1 and 1.2.

Table 1.1 Current data from $10 \%$ to $100 \%$ SOC charge tests

\begin{tabular}{|l|c|c|c|}
\hline Battery Types/SOC & $\begin{array}{c}\% 10 \\
\text { SOC }\end{array}$ & $\begin{array}{c}\% 50 \\
\text { SOC }\end{array}$ & $\begin{array}{c}\% 100 \\
\text { SOC }\end{array}$ \\
\hline LiFePO4 & $79,3 \mathrm{~A}$ & 66,9 & $9 \mathrm{~A}$ \\
& & $\mathrm{~A}$ & \\
\hline $\begin{array}{l}\text { Nickel Metal } \\
\text { Hydride }\end{array}$ & $124,8 \mathrm{~A}$ & $\begin{array}{c}33,09 \\
\mathrm{~A}\end{array}$ & $\begin{array}{c}8,06 \\
\mathrm{~A}\end{array}$ \\
\hline Lead Acit & $200,8 \mathrm{~A}$ & $\begin{array}{c}18,91 \\
\mathrm{~A}\end{array}$ & $\begin{array}{c}3,38 \\
\mathrm{~A}\end{array}$ \\
\hline Nickel Cadmium & $135,3 \mathrm{~A}$ & 34,11 & 7,96 \\
& & $\mathrm{~A}$ & $\mathrm{~A}$ \\
\hline
\end{tabular}

Table 1.2 From $10 \%$ to $50 \%$ and from $50 \%$ to $100 \%$ charging time

\begin{tabular}{|l|c|c|c|}
\hline Battery Types/SOC & $\begin{array}{c}\% 10 \\
\text { SOC }\end{array}$ & $\begin{array}{c}\% 50 \\
\text { SOC }\end{array}$ & $\begin{array}{c}\% 100 \\
\text { SOC }\end{array}$ \\
\hline LiFePO4 & 0 & $25 \mathrm{~min}$ & $1 \mathrm{~h} 5 \mathrm{~min}$ \\
\hline Nickel Metal Hydride & 0 & $41 \mathrm{~min}$ & $\begin{array}{c}1 \mathrm{~h} \\
55 \mathrm{~min}\end{array}$ \\
\hline Lead Acit & 0 & $1 \mathrm{~h} 3 \mathrm{~min}$ & $4 \mathrm{~h}$ \\
\hline Nickel Cadmium & 0 & $40 \mathrm{~min}$ & $2 \mathrm{~h}$ \\
\hline
\end{tabular}

\subsection{LiFePO4 Temperature Test}

In this test, the SOC level of the LiFePO4 battery is selected as $10 \%$ and the specific parameters are left constant. Observations are made between 25-55 degrees Celsius. In order to perform this test, the system is charged with high current to increase the temperature value. At the start of the test it is observed that the system temperature is 25 degrees, the SOC value is $10 \%$ and the charging current is 197 amperes. In addition, the display output is 1 because the system is between the desired temperature values. This indicates that charging is in progress. The test is terminated by the BMS when the temperature reaches 55 degrees Celsius. When the threshold value for the temperature value is exceeded in the control mechanism, the system now analyzes the charge as hazardous and disables the mechanical switches as observed in Figure 11. In this way, the DC supply is disconnected. The current value is 111,6 amperes. The test was successful. The LiFePO4 battery has reached from 25 degrees Celsius to 55 degrees Celsius in 644,8 seconds.

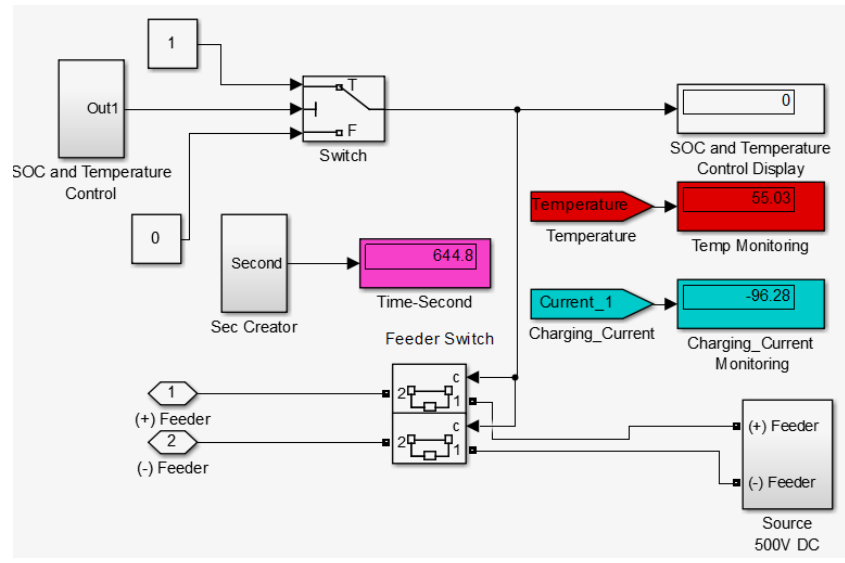

Fig. 11. Charging Temperature for LiFePO4 


\subsection{Nickel Metal Hydride Temperature Test}

In this test, the SOC level of Nickel Metal Hydride battery is selected as 10\% and specific parameters are kept constant. Observations are made between 25-55 degrees Celsius. In order to perform this test and to increase the temperature value, the system is charged with high current. At the start of the test, it is observed that the system temperature is 25 degrees, the SOC value is $10 \%$ and the charging current is 208,8 amperes. In addition, the display output is 1 because the system is between the desired temperature values. This indicates that charging is in progress. The test is terminated by the BMS when the temperature reaches 55 degrees Celsius. When the threshold value for the temperature value is exceeded in the control mechanism, the system now analyzes the charge as hazardous and disables the mechanical switches as observed in Figure 12. In this way, the DC supply is disconnected. The current current value is 64,78 amperes. The test was successful. Nickel Metal Hydride battery has reached 25 degrees Celsius to 55 degrees Celsius in 780.3 seconds.

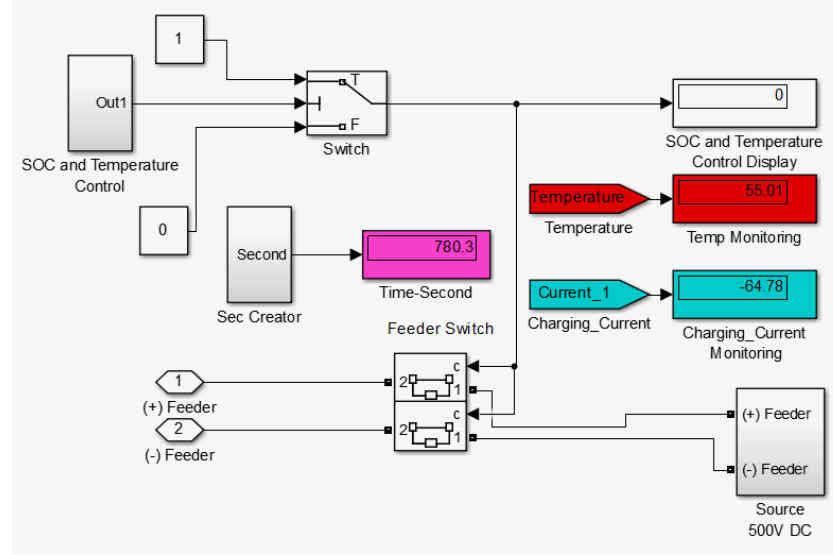

Fig. 12. Charging Temperature for Nickel Metal Hydride

\subsection{Lead Acit Temperature Test}

At the start of the test, it is observed that the system temperature is 25 degrees, the SOC value is $10 \%$ and the charging current is 334.4 amperes. In addition, the display output is 1 because the system is between the desired temperature values. This indicates that charging is in progress. The test is terminated by the BMS when the temperature reaches 55 degrees Celsius. When the threshold value determined for the temperature value is exceeded in the control mechanism, the system now analyzes the dangerous load and disables the mechanical switches as observed in Figure 13. In this way, the DC supply is disconnected. The current current value is 42,66 amperes. The test was successful. Lead Acid battery has reached from 25 degrees Celsius to 55 degrees Celsius in 957 seconds.

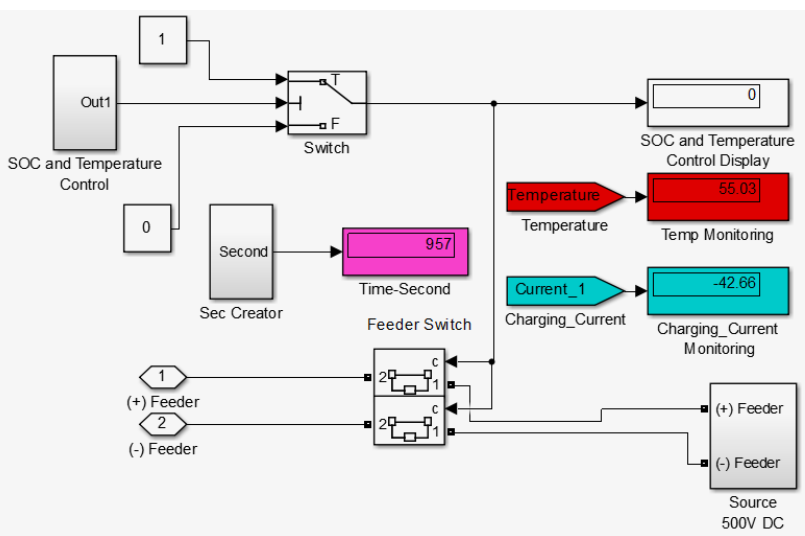

Fig. 13. Charging Temperature for Lead Acit

\subsection{Nickel Cadmium Temperature Test}

At the start of the test, it is observed that the system temperature is 25 degrees, the SOC value is $10 \%$ and the charging current is 225,5 amperes. In addition, the display output is 1 because the system is between the desired temperature values. This indicates that charging is in progress. The nickel cadmium temperature test is terminated when the temperature reaches 55 degrees Celsius by the BMS. When the threshold value determined for the temperature value is exceeded in the control mechanism, the system now analyzes the charge as dangerous and disables the mechanical switches as observed in figure 14. In this way, the DC supply is disconnected. The current current value is 68.21 amperes. The test was successful. The nickel cadmium battery has reached 25 degrees Celsius to 55 degrees Celsius in 758.2 seconds.

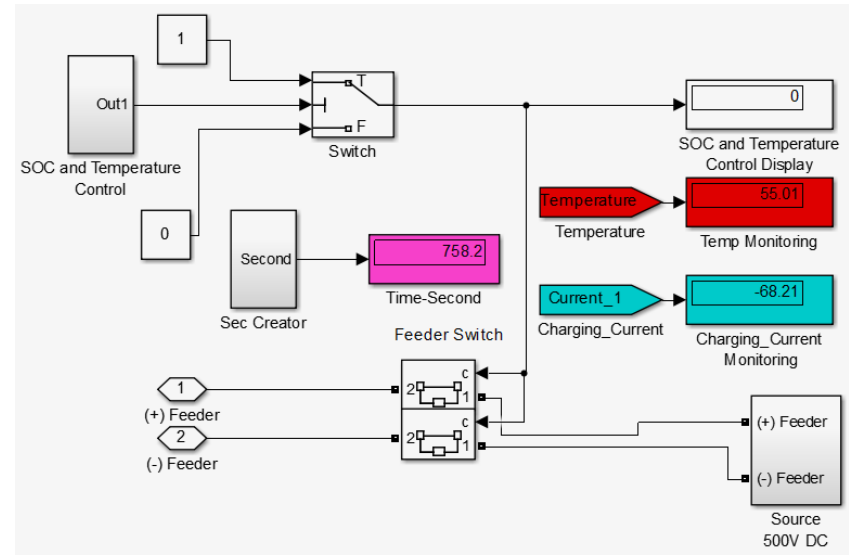

Fig. 14. Charging Temperature for Nickel Cadmium 
The comparisons of four different types of batteries at the end of the temperature test are presented in Table 1.3.

Table 1.3 Temperature time for Batteries

\begin{tabular}{|c|c|c|c|}
\hline \multicolumn{4}{|c|}{ TEMPERATURE TIME $\left(25-55^{\circ} \mathrm{C}\right)$} \\
\hline & Start $\left({ }^{\circ} \mathrm{C}\right)$ & $\begin{array}{c}\text { End of the } \\
\text { test }\left({ }^{\circ} \mathrm{C}\right)\end{array}$ & $\begin{array}{c}\text { Time } \\
(\text { second })\end{array}$ \\
\hline LiFePO4 & 25 & 55 & 644,8 \\
\hline $\begin{array}{c}\text { Nickel Metal } \\
\text { Hydride }\end{array}$ & 25 & 55 & 780,3 \\
\hline Lead Acit & 25 & 55 & 957 \\
\hline $\begin{array}{c}\text { Nickel } \\
\text { Cadmium }\end{array}$ & 25 & 55 & 758,2 \\
\hline
\end{tabular}

\subsection{LiFePO4 Driving Test}

In this test, the charge and discharge characteristics of the LiFePO4 battery according to the driving scenario will be examined. The pre-test $\mathrm{LiFePO} 4$ battery has a fill rate of $20 \%$ and a test time of 1 hour. At the end of the test, the working status of the BMS was examined. At the end of the first test, it has been observed that the battery management system controls the batteries properly while the hybrid electric vehicle is running and when the minimum battery reaches the discharge point, it prevents the discharge of the batteries and then activates the parameters that enable the batteries to charge. This test was successful for the battery SOC control of the battery management system. At the end of the test, the LiFePO4 has \%60 SOC.

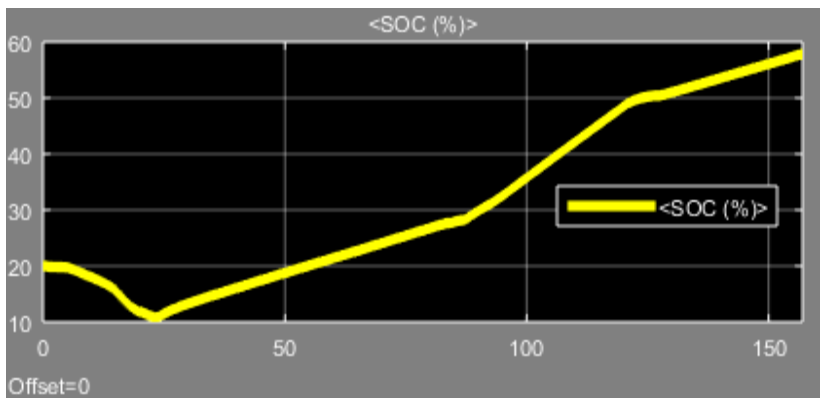

Fig.15 Driving test for LiFePO4

\subsection{Nickel Metal Hydride Driving Test}

In this test, the charge and discharge characteristics of Nickel Metal Hydride battery according to the driving scenario shall be examined. The pre-test nickel metal hydride battery has been selected as $20 \%$ and the test period is 1 hour. At the end of the test, the working status of the BMS was examined. At the end of the second test, it was observed that the BMS controls the charging and discharging of the batteries while the hybrid electric vehicle is running, the battery occupancy rate prevents the discharge when the minimum point is reached and the batteries start charging process. At the end of the test, the
Nickel Metal Hydride battery had a $20 \%$ initial capacity and increased to $52 \%$.

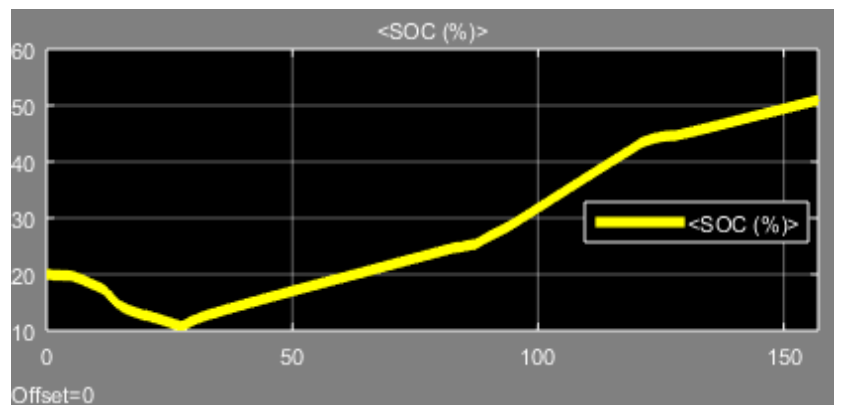

Fig.16 Driving test for Nickel Metal Hydride

\subsection{Lead Acit Driving Test}

In this test, the charge and discharge characteristics of the Lead Acid battery according to the driving scenario will be examined. The pre-test Lead Acid battery has been selected as $20 \%$ and the test period is 1 hour. At the end of the test, the working status of the BMS was examined. At the end of the test, it was observed that the BMS was actively operated and when the occupancy rate reached $10 \%$, the batteries were discharged and the charging process started. The NIS has thus prevented the death of the battery cells. A healthier battery operation is provided. As a result of the lead acid battery test, the SOC of the battery is $33 \%$.

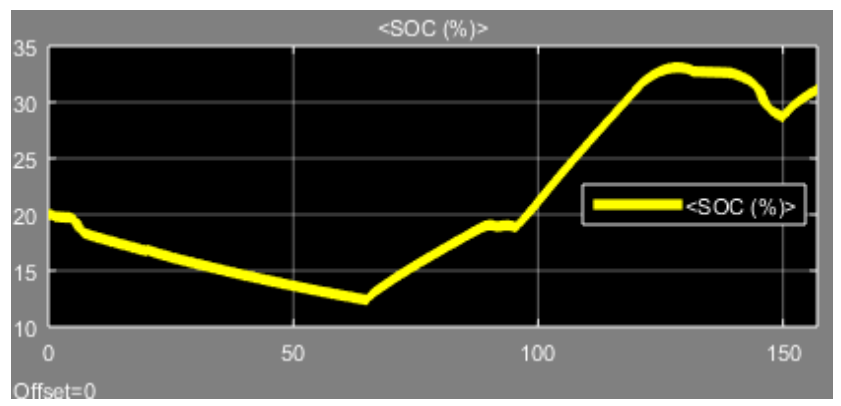

Fig.17 Driving test for Lead Acit

\subsection{Nickel Cadmium Driving Test}

In this test, charge and discharge characteristics will be examined according to driving scenario of Nickel Cadmium battery. Before the test, the occupancy rate of Nickel Cadmium battery is $20 \%$ and the test period is 1 hour. At the end of the test, the working status of BMS was examined. At the end of the test, it was observed that BYS was active and the battery pack was switched from discharge to charge when the battery pack was at minimum occupancy rate. At the end of the test, the battery had a SOC of 50\%. 


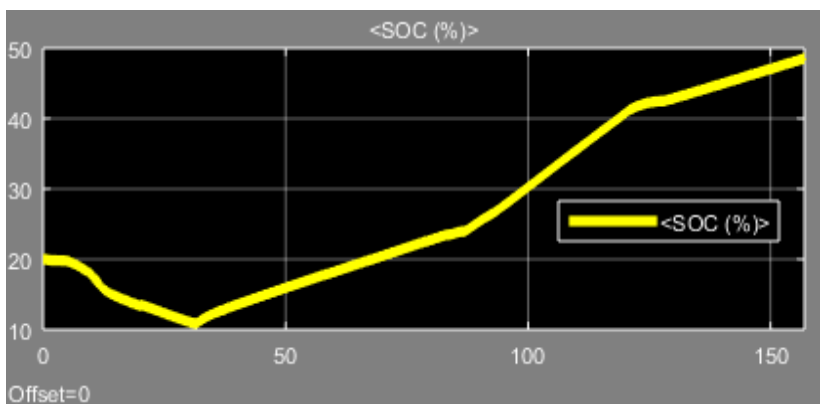

Fig.18 Driving test for Nickel Cadmium

For four different types of battery, the resulting SOC values at the end of the driving scenario are presented in Table 1.4.

Table 1.4 SOC value at the and of the driving scenario

\begin{tabular}{|c|c|c|c|}
\hline \multicolumn{4}{|c|}{ SOC (\%) } \\
\hline & $\begin{array}{c}\text { Start } \\
\text { SOC }\end{array}$ & $\begin{array}{c}\text { Lowest } \\
\text { SOC }\end{array}$ & $\begin{array}{c}\text { End of the } \\
\text { Test }\end{array}$ \\
\hline LiFePO4 & $\% 20$ & $\% 10$ & $\% 60$ \\
\hline $\begin{array}{c}\text { Nickel Metal } \\
\text { Hydride }\end{array}$ & $\% 20$ & $\% 10$ & $\% 52$ \\
\hline Lead Acit & $\% 20$ & $\% 10$ & $\% 33$ \\
\hline $\begin{array}{c}\text { Nickel } \\
\text { Cadmium }\end{array}$ & $\% 20$ & $\% 10$ & $\% 50$ \\
\hline
\end{tabular}

\section{Conclusion}

In this study, charge and discharge characteristics of four different battery types were investigated. Three different tests were made with batteries. In the first test, the batteries were charged with a charger and the charging times, charging currents were examined. In the second test, the temperature values during charging were analyzed and in the final test, the charge and discharge characteristics were examined on a hybrid vehicle model. According to the test results, the following comments can be made:

1- The battery type with the highest charge current at the start of charging was LiFePO4.

2- The fastest rechargeable battery is Lithium Iron Phosphate.

3- The slowest rechargeable battery is Nickel Cadmium.

4- The most efficient type of battery is lithium iron phosphate.

5- The most inefficient type of battery is Nickel Cadmium.

6- The LiFePO4 battery is the fastest warming battery.

7- Nickel Metal Hydride battery is the slowest warming battery.

\section{References}

[1] A. Khaligh and Z. Li (2010). Battery, ultracapacitor, fuel cell, and hybrid energy storage systems for electric, hybrid electric, fuel cell, and plug-in hybrid electric vehicles: State of the art. IEEE Trans. Veh. Technol., vol. 59, no. 6, pp. 2806-2814. [2] B. Divakar, K. Cheng, and H. Wu (2009).Battery management system and control strategy for hybrid and electric vehicle. 2009 3rd International Conference on Power Electronics Systems and Applications, pp. 1-6.

[3] K. S. Lee, C. J. Moon, T. G. Kim, M. S. Jeong, S. M. Kim, and B. J. Park 2012). A development of battery monitoring and management system. 2012 IEEE Veh. Power Propuls. Conf. VPPC 2012, pp. 428-430.

[4] J. D. Welsh (2009). A Comparison of Active and Passive Cell Balancing Techniques for Series / Parallel Battery Pack, p. 115 .

[5] S. O. U. R. Past (2013). THE RISE \& FALL OF ELECTRIC. vol. 101, no. 1, pp. 206-212.

[6] Galen Handy, "Electric Cars," Electric Cars. [Online]. Available: http://www.edisontechcenter.org/ElectricCars.html.

[7] C. Johan and B. Svard 2003). Impact on global metal flows arising from the use of portable rechargeable batteries. The Science of the Total Environment, vol. 302, pp. 167-184.

[8] E. Renault, F. Araci, and U. Üniversitesi. Renault Fluence Ze, Li-Ion Battery Modelling And Battery Management. pp. 7582.

[9] Z. Shahan, "Electric Car Evolution," 2015. [Online]. Available: https://cleantechnica.com/2015/04/26/electric-carhistory/.

[10] Y. E. Ekici and N. Tan (2018). Farklı Batarya Tiplerinin Şarj ve Deşarj Karakteristiklerinin Hibrit Araç Modeli Üzerinde İncelenmesi. International Conference on Innovative Engineering Application, pp. 1-8.

[11] E. EKİCI and N. TAN (2018). Investigation Of Charging And Discharging Characteristics Of Different Type Batteries On Hybrid Electric Vehicle Model. $3^{\text {rd }}$ International Energy and Engineering Conference, pp. 735-748.

[12] E. EKİCI and N. TAN (2018). Investigation of Charging and Discharging Characteristics of Different Type Batteries on Hybrid Electric Vehicle Model. The International Journal of Energy \& Engineering Sciences, vol. 3, no. 3, pp. 55-67.

[13] M. R. Jongerden and B. R. Haverkort (2009). Which battery model to use?. IET Software, vol. 3, no. 6, p. 445. 